\title{
Influence of various growing media on growth and flowering of zinnia (Zinnia elegans) Dreamland
}

\author{
Abdul Qadir Gola ${ }^{1}$, Muhammad Iqbal Jakhro ${ }^{2 *}$, Maliha Habib ${ }^{3}$, Sher \\ Ahmed $^{2}$, Muhammad Akbar Badini ${ }^{1}$, Mohammed Wafa Shahwani ${ }^{1}$, \\ Noor Samad Naseer ${ }^{2}$ and Syed Ishtiaq Ahmed Shah ${ }^{1}$ \\ 1. Sindh Agriculture University, Tandojam-Pakistan \\ 2. PARC Balochistan Agricultural Research and Development Centre Brewery Road, Quetta-Pakistan \\ 3. Sardar Bahadur Khan Women University Brewery Road, Quetta-Pakistan \\ *Corresponding author's email: iqbal.jakhro@gmail.com
}

Citation

Abdul Qadir Gola, Muhammad Iqbal Jakhro, Maliha Habib, Sher Ahmed, Muhammad Akbar Badini, Mohammed Wafa Shahwani, Noor Samad Naseer and Syed Ishtiaq Ahmed Shah. Influence of various growing media on growth and flowering of zinnia (Zinnia elegans) Dreamland. Pure and Applied Biology. Vol. 7, Issue 3, pp946-954.

http://dx.doi.org/10.19045/bspab.2018.700113

Received: 03/04/2018 Revised: 05/07/2018

Accepted: 07/07/2018

Online First: 19/07/2018

\section{Abstract}

The present study was conducted to evaluate of different growing media on the growth and flowering of Zinnia elegans. The Seven various growth media including soil loam, (Silt+ Bagasses+ Soil: 1:1:1) and silt+ leaf manure+ soil, (Silt+ Banana leaves+ Bagases+ Soil: 1:1:1). Silt+ Cattle manure+ Fruit vegetable+ Banana leaves. (Silt+ Goat manure+ Cattle+ manure+ Leafe manure: 1:1:1:1) were used for growing Zinnia. The research and during the seasons, 2017 respectively, in the experimental site at the Balochistan agricultural research and development centre, Pakistan. In three replication the experiment was layout in complete randomized design CRD. It provided equivalent importance to treatments. Number of branches per plant, plant height, numbers of leaves, days taken to open first flower, flowers per plant, single flower weight, blooming period and total were determined. The current study approves the fact that selection of the suitable medium of growth for potted flowering plants in this case Z. elegans was very vital from aesthetic and promotion point of view. The average necessity make sure the plant production of the obligatory superiority on cost effective basis. The current study determined leaf manure produced significantly the maximum vase life and diameter of flower while the maximum vase life and diameter of flower was obtained, it results evaluated research study that different growing media might be effectively used to obtain superior worth and yield.

Keywords: Agricultural waste; Dreamland; growing media; Zinnia

\section{Introduction}

Z. elegans are among the most glorious flower of summer annuals planted in Quetta. It belongs to family Compositae and is native to Mexico and Central America. It is easy to cultivate, grown well in full sun and standing good in very hot weather and has beautiful cut flowers with wide variability in colour and shape. The flowers display cheerful colours with study stems and 
reasonably long vase life and that's why gaining fame as specialty cut flower [1]. However, the height ranges from $15 \mathrm{~cm}$ to 1 meter. Zinnia is a genus of 20 species and notable for their solitary. The flowers that come in a variety of bright colours with a shape stretching from linear to ovate and pale to medium green in colour. Flowers have a range of presences a single row of petals, to a dome shape, covered in different colours white, chartreuse, yellow, orange, red, purple, and lilac. Zinnias are most famous garden flower is various benefits like to use borders, beds, edges and cut flowers to be an excellent source of overseas exchange [2]. Observance in outlook the standing of different growing media smooth with esteem to existing study was planned to comprehend the influence of dissimilar levels of organic manure [3]. The growth appearances and flowers of Z. elegans agro climatic conditions of Quetta, Pakistan. Floriculture industry is gradually developing in Pakistan. Nursery and flower professional is growing progressively by reason of enrichment in aesthetic perception of the societies. Plant market raising and potting of annuals are vital actions in nurseries specialty cut flower farms. But before farmers practice among nursery flowers growers in Pakistan is the use of soil, silt and farmyard leaf manure as conservative substrates. Too much usage of farmyard manure for others agricultural and energy production due to decreasing availability of farmyard manure $[4,5]$. Production and use of cut flowers has also improved decade and this rise is projected to carry on due to number of indeterminate causes in Pakistan [6]. One of the supreme imperative features in cut flower production is proper quantity of nutrition through the growing period [7], several plant growth regulators have acknowledged outcome to upsurge the vase life of flowers and they can be capably used to augment the shelf life of flowering crops
[8]. The mixture plant leaves compost leaf manure is provide essential nutrients and better growth for plant. Water holding capacity rise fruit manure and enrich manure the nutrient stock capability in soil growing media [9]. Compost is excellent method for maximum growth and enrich the essential nutritional value for plant. [10]. The pot production of different types of plants especially miniature zinnia is most popular in urban dwellings. For this garden soil, leaf compost and fruit manure are the developing substrates preferably method designed for container production couple of years yearly and lasting ornamental plants [11]. Respectable flower production frequently be contingent upon numerous influences plus the type of growing media used. Growing media is distinct as the mean where the roots of cultivated plants grow [12]. Furthermore, it is generally manageable. There is an improving movement to exploit various farming by-products and organic wastes being nutrient causes for ornamental container planted plants by reason of several common features with peat [13]. Growing media has been extensively implemented emergent substrate because of it is provide excellent physical and chemical properties, however its possessions are lessening, consequently it would be wise to treasure substitute substances [14]. Pure soil, silt, bagases, leaf manure, cattle manure, fruit vegetable, banana leaves and soil mixture were used to evaluate their effects on the growth and flowering of Zinnia to observe the suitable growing media for this species. Good flower production frequently depends upon numerous causes as well as the type of growing media used. Growing media is defined as the mean where the roots of cultured plants grow [12]. In Pakistan, Zinnia is grown in several forms of soils, soil mixtures, or combinations of organic matter and materials without soil that may include sand, peat, prelate, bark and wood 
chips, sludge, or else composted leaves. The growing media have to be porous, uniform in texture, hold sufficient moisture and should be well drained. Commercial combinations are every so often used because they are purified, ready to use and might straight comprise some fertilizer. The valuable consequence of grouping of different types of fertilizers encompassing macro and micronutrients on growth parameters of Zinnia are well familiar [15]. Currently, in Pakistan less work has been carried out on this flowering plant using different growth media sources. Most of the farmers are using chemical fertilizers and peat in order to attain maximum production of flowering plants. The current study is being proposed to study the effect different growing media on growth and flowering of Zinnia (Z. elegans) plant.

\section{Materials and methods}

The research was conducted during the year 2017 in a complete randomized design (CRD) The pot experiment of the garden at Balochistan agriculture research \& development centre, Quetta. Present research work the seeds $Z$. elegans var. variety of Dreamland seed under various growing media were used for field study.

\begin{tabular}{ccc}
\multicolumn{2}{c}{ Dissimilar treatment mixtures of agricultural wastes used as growing media } \\
Treatments & mixtures & Volume \\
T1 & Control 100\% (Soil) & $1: 0$ \\
T2 & Sand + Bagasse + Soil & $1: 1: 1$ \\
T3 & Sand + Leaf manure + Soil & $1: 1: 1$ \\
T4 & Sand + Banana leaves + Bagasse + Soil & $1: 1: 1: 1$ \\
T5 & Sand +Cattle manure +Fruit vegetable + Banana leaves & $1: 1: 1: 1$ \\
T6 & Sand + Goat manure + Cattle manure +leaf manure & $1: 1: 1: 1$
\end{tabular}

\section{Statistical analysis}

All collected data were analyzed concluded a statistical computer software named Statistix 8.1 [16]. LSD test was performed. The data were exposed to analysis of modification technique and means were matched via least significant at $(\mathrm{P} \leq 0.05)$. Probability level to compare treatment superiority.

\section{Results and discussion}

Plant height

The effect on plant height of $Z$. elegans was assessed and the results are shown in (Table 1). It is assumed from the analysis of difference plant height of $Z$. elegans was significantly $\quad(\mathrm{P}<0.05) \quad$ affected this treatments. The produced Zinnia plants of maximum height $(45.27 \mathrm{~cm})$, while the Zinnia developed under various media treatment comprised of after five days the produced plants $(42.35 \mathrm{~cm})$ height. Similarly, the Zinnia grown the different treatments on media the plants produced relatively shorter height were in control $(41.43 \mathrm{~cm})$. The results clearly suggested that growing of Zinnia under various media was the best treatment; and decreasing daylight resulted in significant $(\mathrm{P}<0.05)$ rise in plant heights. Although, imposing the under Green house at nursery BARDC Quetta. But the plants grew faster when the daylight imposed. Certainly the adverse of effects on the plants and consequently, slowing growth was observed. But still better this condition. Daylight, sunshine and temperature greatly influence the plant vegetative growth and crop production. These results are further, supported by many researches [17] reported that $2 / 5$ days of Zinnia existed the furthermost effective to give cheerful growth and flowering [18] reported that the days of photosynthesis and light integral are the most important aspects for the ornamental plants which are the 
mainly growth for their proper growth and flowering purpose [19]. Reported that various grown species at $20 / 14{ }^{\circ} \mathrm{C}$ remained $10 \%$ to $41 \%$ higher compared than grown at $16 / 22{ }^{\circ} \mathrm{C}$ and results has a settlement with those conveyed by [20] noted maximum plant height of Zinnia at same media. The finest levels of different media combine advanced results maximum stem development in the Zinnia.

Table 1. Plant height (cm) of Zinnia as affected by various salinity levels

\begin{tabular}{|c|c|c|c|c|}
\hline Treatments & R1 & R2 & R3 & Means \\
\hline 1 & 30.1 & 25.2 & 23.25 & $26.18 \mathrm{e}$ \\
\hline 2 & 36.2 & 37.2 & 34.5 & $35.96 \mathrm{~d}$ \\
\hline 3 & 38.4 & 40.2 & 35.3 & $37.96 \mathrm{~cd}$ \\
\hline 4 & 41.3 & 42.2 & 43.56 & $42.35 \mathrm{ab}$ \\
\hline 5 & 45.3 & 46.23 & 44.3 & $45.27 \mathrm{a}$ \\
\hline 6 & 42 & 40 & 42.3 & $41.43 \mathrm{bc}$ \\
\hline
\end{tabular}

$\mathrm{SE} \pm=1.6158$

LSD $0.05=3.600$

\section{Number of branches per plant}

The response of $Z$. elegans to under various media in treatments relation to the number of side branches plant-1 was examined and the results are presented in (Table 2). It was perceived from the exploration variance that side branches plant-1 were significantly $(\mathrm{P}<0.05)$ influenced in variation. Zinnia plants under different media in treatment of daylight the produced maximum number of side branches (7.55), while the Zinnias developed under various media in treatment comprised of 5 days produced (7.01) side branches plant-1. Likewise, Zinnia grown under various media treatment of daylight produced relatively lesser number of side branches (5.66); whereas, the lesser number of side branches per plant were observed in control treatment, where Zinnia plants were developed under natural different organic manure. It was observed that growing Zinnia under various media was the best treatment in relation to development of side branches plant-1 and decrease in light resulted in a significant $(\mathrm{P}<0.05)$ decrease in the, It was observed that imposing growth media including soil silty loam, (Silt+ Bagasses+ Soil: $1: 1: 1$ ) and silt+ leaf manure+ Soil, (Silt+ Banana leaves+ Bagases+ Soil: 1:1:1). Silt+ Cattle manure+ Fruit vegetable+ Banana leaves. (Silt+ Goat manure+ Cattle+ manure+ Leafe manure: 1:1:1:1 were used for growing Zinnia. restricted daylight for particular hours and the plants developed more side branches as compared to natural organic manure. However, curtailing to showed adverse effects on the plants vegetative growth and in result sprouting of side branches was checked. Study is in pursuance with [21]. The positively associated with the plant height and the number of side branches plant ${ }^{-1}$. Under various media, and the plant growth was checked which is sunrays, reflected to increased. These results are an agreement with $[22,23,20]$ discovered out that increase in under various media have significant effect on number of branches per plant with leaf area.

\section{Number of leaves per plant}

$Z$. elegans growth response to under varied media in terms of leaves plant- 1 was studied and the data are shown in (Table 3). Analysis of difference showed the total number of leaves per plant of zinnia were significantly $(\mathrm{P}<0.05)$ affected in variation in organic manure. Zinnia plants under various media in treatment the produced highest number of leaves (44.62), while Zinnias grown under different treatment comprised the produced (40.70) leaves plant ${ }^{-}$ 1. Similarly, Zinnia grown under various 
organic manure, the treatment of produced in relatively reduced number of leaves (40.00); although excessive total leaves per plant found in (control) treatment someplace the Zinnia plants developed under various natural organic manure. The results showed that growing of Zinnia under various media. It was an appropriate in relation to that increase in various organic manure has significant effect on the number of leaves plant $^{-1}$.

Table 2. Number of branches per plant of Zinnia as affected by various salinity levels

\begin{tabular}{|c|c|c|c|c|}
\hline Treatments & R1 & R2 & R3 & Means \\
\hline 1 & 4.25 & 3.2 & 4.3 & $3.91 \mathrm{c}$ \\
\hline 2 & 5.3 & 4.2 & 5.3 & $4.93 \mathrm{bc}$ \\
\hline 3 & 5.3 & 6.3 & 5.4 & $5.66 \mathrm{~b}$ \\
\hline 4 & 6.7 & 7.75 & 6.6 & $7.01 \mathrm{a}$ \\
\hline 5 & 7.65 & 7.4 & 7.6 & $7.55 \mathrm{a}$ \\
\hline 6 & 5.6 & 5.3 & 5.20 & $5.30 \mathrm{~b}$ \\
\hline
\end{tabular}

$\mathrm{SE} \pm=0.4596$

LSD $0.05=1.0240$

Table 3. Numbers of leaves plant ${ }^{-1}$ of Zinnia as Affected by Various Salinity Levels

\begin{tabular}{|c|c|c|c|c|}
\hline Treatments & R1 & R2 & R3 & Means \\
\hline 1 & 30 & 32 & 30 & $30.66 \mathrm{e}$ \\
\hline 2 & 32 & 36 & 33 & $33.66 \mathrm{~d}$ \\
\hline 3 & 36.2 & 37.1 & 35 & $36.10 \mathrm{c}$ \\
\hline 4 & 40.3 & 42.52 & 39.3 & $40.70 \mathrm{~b}$ \\
\hline 5 & 44.35 & 46.3 & 43.22 & $44.62 \mathrm{a}$ \\
\hline 6 & 42.3 & 40.5 & 37.2 & $40.00 \mathrm{~b}$ \\
\hline
\end{tabular}

$\mathrm{SE} \pm=0.9621$

LSD $0.05=2.1438$

\section{Days taken to first flower}

Days to initiate first Flower of Zinnia grown under various media to examine the effect on the number of days taken by the plants to initiate flower the results to this effect mentioned in (Table 4). Analyzed variance described significant impact on different media $(\mathrm{P}<0.05)$ on the total days engaged initiate flower. Zinnia grown under various treatment in comprised the less days to initiate flower (51.10), while the Zinnias developed under various media the days to 4 initiate flower. Similarly, Zinnia grown under different media of 4 took more days to initiate flower bud (46.50); while the maximum number of days to initiate flower bud were recorded in control treatment (45.30), where Zinnia plants were developed under natural organic manure. The number of days reserved to initiate bud was inversely comparative to accumulative daylight. Zinnia plants showed earliness to initiate flower bud and with decrease in daylight hours resulted in delayed initiation of flower bud [24]. Reported that buds took less time and the Zinnia under warmer temperatures and longer day lengths. It means that natural organic manure interrelated using collectively and an intensification resource in plant eventually relief plants to consume more in hefty amount, of flower so ideal ranks couple of mandatory for primary flower production in plants. Potential plant on focus vegetative progression instead reproductive better growth of flower. To increase the number of short days increased in initial flower bud number. 
Table 4. Taken days to open $1^{\text {st }}$ Zinnia flower affected on various salinity levels

\begin{tabular}{|c|c|c|c|c|}
\hline Treatments & R1 & R2 & R3 & Means \\
\hline 1 & 51.6 & 49.2 & 49.5 & $51.10 \mathrm{a}$ \\
\hline 2 & 48.9 & 45.2 & 45.4 & $46.50 \mathrm{~b}$ \\
\hline 3 & 45.3 & 45.2 & 45.4 & $45.30 \mathrm{~b}$ \\
\hline 4 & 42.3 & 42.2 & 42.7 & $42.40 \mathrm{c}$ \\
\hline 5 & 41.7 & 41.6 & 41.95 & $41.75 \mathrm{c}$ \\
\hline 6 & 42.7 & 42.6 & 42.5 & $42.60 \mathrm{c}$ \\
\hline
\end{tabular}

SE $\pm=0.7503$

\section{LSD $0.05=1.6718$}

\section{Weight of single flower}

The effect of organic manure on weight of single flower in Zinnia was examined and the results to this effect are presented in (Table 5). The analysis described significant impact on media of different single weight of flower $(\mathrm{P}<0.05)$. Zinnia plants developed under various media and produced heaviest flowers $(6.86 \mathrm{~g})$, while the zinnias grown under organic manure and produced flowers of $(6.41 \mathrm{~g})$ weight on average. Similarly, Zinnia grown under various natural organic manure produced average flower weight of (6.32) $\mathrm{g}$; while the longest weight of single flower on average was recorded control treatment (5.81), where the zinnia plants were developed under natural organic manure this higher weight of single flower was mainly too associated with the increased flower diameter. The results also suggested that increasing the flower produced healthier zinnia plants and produced healthy flowers. Hence, for achieving healthy zinnia flowering, the [25] suggested the ornamental plants flowering at $20^{\circ} \mathrm{C}$ and days harvest bud smaller amount of zinnia under heater temperatures and lengthier day produced heavier flowers (6.86g) [26] notified increased flowering (6.41g) and weight (6.32g.).

Table 5. Single flower weight (g) of Zinnia as affected by various salinity levels

\begin{tabular}{|l|l|l|l|l|}
\hline Treatments & R1 & R2 & R3 & Means \\
\hline 1 & 4.2 & 3.3 & 3.4 & $3.63 \mathrm{~d}$ \\
\hline 2 & 4.3 & 4.8 & 4.3 & $4.46 \mathrm{c}$ \\
\hline 3 & 5.8 & 4.9 & 4.85 & $5.18 \mathrm{~b}$ \\
\hline 4 & 6.4 & 6.5 & 6.35 & $6.41 \mathrm{a}$ \\
\hline 5 & 6.85 & 6.9 & 6.85 & $6.86 \mathrm{a}$ \\
\hline 6 & 6.3 & 6.38 & 6.3 & $6.32 \mathrm{a}$ \\
\hline
\end{tabular}

$\mathrm{SE} \pm=0.2542$

LSD $0.05=0.5664$

\section{Flowering per plant}

Z. elegans response to under varied organic manure in terms of flowers plant ${ }^{-1}$ was studied and the results are shown in (Table 6). It was identified that flowers plant ${ }^{-1}$ of Zinnia were significantly $(\mathrm{P}<0.05)$ affected by various media. The Zinnia plants under organic manure the produced highest number of flowers (10.80), while the Zinnias grown under various media comprised (1033) flowers plant ${ }^{-1}$. Similarly, the Zinnia grown under control treatment where the
Zinnia plants were developed under natural organic manure (1014) flowers plant ${ }^{-1}$, while the produced lowest number of flowers (8.56) plant $^{-1}$. This higher number of flower plant $^{-1}$ under the mainly associated with the increased plant height, side branches and leaves plant $^{-1}$, as these parameters improved, the flowers plant $^{-1}$ were increased simultaneously [27]. Further, reported that Arabidopsis thaliana flower within 31 days at $22{ }^{\circ} \mathrm{C}$ whereas flower formation was late until 63 days when the temperature was 
summarize to $14{ }^{\circ} \mathrm{C}$. The results recommend that temperature affects time and rate of flower production [19]. Reported that when ornamental plants at $16^{\circ} \mathrm{C}$ or $200 \mathrm{C}$ were grown with short day or long day further, they found that quicker flowering were found at $16^{\circ} \mathrm{C}$ but best is $21^{\circ} \mathrm{C}$.

Table 6. Flowers per plant of Zinnia as affected on various salinity levels

\begin{tabular}{|l|l|l|l|l|}
\hline Treatments & R1 & R2 & R3 & Means \\
\hline 1 & 5.6 & 5.9 & 5.8 & $5.76 \mathrm{e}$ \\
\hline 2 & 7.1 & 7.2 & 7.33 & $7.21 \mathrm{~d}$ \\
\hline 3 & 8.6 & 8.5 & 8.6 & $8.56 \mathrm{c}$ \\
\hline 4 & 10.2 & 10.3 & 10.5 & $10.33 \mathrm{~b}$ \\
\hline 5 & 10.8 & 10.9 & 10.7 & $10.80 \mathrm{a}$ \\
\hline 6 & 10.2 & 10.1 & 10.12 & $10.14 \mathrm{~b}$ \\
\hline
\end{tabular}

$\mathrm{SE} \pm=0.0914$

LSD $0.05=0.2036$

\section{Blooming period (days)}

The results to this effect are presented in (Table 7), which showed significant effect of different organic manure $(\mathrm{P}<0.05)$ on the blooming period. The Zinnia plants grown under various media treatment comprised to showed highest blooming period (42.25 days), while the Zinnias developed under natural organic manure and treatment comprised of the resulted in (41.53 days), blooming period. Similarly, the blooming period was (41.35 days), in Zinnia grown under control treatment. However, the lowest blooming period of (38.73 days), was observed in Zinnia plants developed. It was observed that growing Zinnia under various organic manure was an appropriate in relation to prolonged blooming period. It was further noted that the blooming period of Zinnia was severely affected. This indicated that night time was harmful for the
Zinnia as far as the blooming period is concerned. Unlike during flowering of initiation, the longest shelf life. The total flower numbers decreased from 45 flowers to 13 flowers Kalanchoe uniform (a short day plant). [28] reported improvement in flower quality with increase in various organic manure in Zinnias developed under control while the leaf chlorophyll content was $25 \%$ and 21 percent in Zinnias grown under sunrays the treatments comprised of respectively. It was observed that increasing the resulted significant $(\mathrm{P}<0.05)$ to improve leaf chlorophyll content over control; more than the control. Hence, growing Zinnia under various organic manure proved to be most effective with $35.17 \mathrm{oC}$ and reduction in daylight would be harmful for leaf chlorophyll content in Zinnia. The magnitude of the delay increased as the duration of the extension lighting increased.

Table 7. Blooming period of Zinnia as affected by various salinity levels

\begin{tabular}{|c|c|c|c|c|}
\hline Treatments & R1 & R2 & R3 & Means \\
\hline 1 & 32.5 & 32.33 & 32.6 & $32.47 \mathrm{e}$ \\
\hline 2 & 35.6 & 35.8 & 35.8 & $35.3 \mathrm{~d}$ \\
\hline 3 & 38.6 & 38.8 & 38.8 & $38.73 \mathrm{c}$ \\
\hline 4 & 41.3 & 41.6 & 41.7 & $41.53 \mathrm{~b}$ \\
\hline 5 & 42.3 & 42.2 & 42.25 & $42.25 \mathrm{a}$ \\
\hline 6 & 41.3 & 41.65 & 41.1 & $41.35 \mathrm{~b}$ \\
\hline
\end{tabular}

$\mathrm{SE} \pm=0.1364$

LSD $0.05=0.3039$ 


\section{Conclusion}

Wholly organic waste substrates presented progressive characteristic to growth and flowering of Zinnia together eagerly convenience of nutrients for uptake. Consequently, it is concluded that suggested agricultural waste debris be able to use provided positive results and vegetative reproductive growing media for better, $Z$. elegans. Plant can be reconnoitred auxiliary for extra combinations.

\section{Authors' contributions}

Conceived and designed the experiments: A Qadir \& MI Jakhro, Performed the experiments: M Habib, S Ahmed \& MA Badini, Analyzed the data: M Habib \& MW Shahwani, Contributed reagents/ materials/ analysis tools: NS Naseer \& SIA Shah, Wrote the paper: A Qadir \& MI Jakhro.

\section{References}

1. Ahmad I \& Dole JM (2014). Homemade floral preservatives affect postharvest performance of selected specialty cut flowers. Hort Technol 24(3): 384-393.

2. Salem BA, Nafees $M$, Farooq $M$ \& Sadaqat HA (2003). Genetic variability estimation for growth characteristics in Zinnia elegans Jacq Across different population densities. Inter $J$ Agri and Biol Sci 5(4): 496-498.

3. Shahid GA, Sajid M \& Amanulah (2014). Response of Dhalia to different levels of nitrogen alone and in combination with constant doses of phosphorus and potassium. American Eurasian J of Sustainable Agri 1(1): 2532.

4. Pramuk LA \& Runkle ES (2005). Modeling growth and development of celosia and impatiens in response to temperature and photosynthetic daily light integral. $J$ American Society of Hort Sci 130(6): 813-818.

5. Stanton KM, Weeks SS, Dana MN \& Mickelbart MV (2010). Light Exposure and Shade Effects on Growth, Flowering, and Leaf Morphology of Spiraea alba Du Roi and Spiraea tomentosa L. Hort Sci 45(12): 19121916.

6. Riaz T, Khan SN \& Javaid A (2007). Scenario of gladiolus production in Punjab, Pakistan. Pak J Bot 39(7): 2389-2393.

7. Abbasi NA, Zahoor S \& Nazir K (2004). Effect of preharvest phosphorus and potassium fertilizers and postharvest $\mathrm{AgNO}_{3}$ pulsing on the postharvest quality and shelf life of Zinnia (Zinnia elegans cv. Blue point) cut flowers. Inter $J$ of Agri and Biol 6(1): 129-131.

8. Peng X, Rao J \& Zhang L (2007). Effect of exogenous salicylic acid on vase life of cut flower of Prato lily and related physiological influence. Acta Hort. Sinica. 34(1): 189-192.

9. Chong C (2005). Experiences with waste and composts in nursery substrates. Hort Technol 15: 739-747.

10. Ostos JC, Garrido RL, Murillo JM \& Lopez R (2008). Substitution of peat for municipal solid-based composts in nursery growing media: Effect on growth and nutrition of the native shrub Pistacia lentiscus L. Bioresource Technol 99(6): 1793-1800.

11. Tariq U, Rehman SU, Khan MA, Younis A, Yaseen M \& Ahsan M (2012). Agricultural and municipal waste as potting media components for the growth and flowering of Dahlia hortensis 'Figaro'. Turkish $J$ of Bot 36(4): 378-385.

12. Kampf AN (2000). The substrate Commercial production of ornamental plants. Guaba: Agriculture. pp 254.

13. Mikkelsen RL (2003). Using tobacco by-products as a nitrogen source for container-grown house plants. J of Plant Nutrition 26(8): 1697-1708. 
14. Wilson SB, Mecca LK, Danielson HE, Graetz DA \& Stoffella PJ (2006). Container and field evaluation of three native shrubs grown in compost-based media. Compulsory Sci Utilization 14(3): 178-183.

15. Bihari M, Surya N \& Singh AK (2010). Effect of pruning levels and biofertilizer on production of rose cut flower. Indian J Hort 67: 367-371.

16. Statistix, 2006. Analytical Software. Statistix 8.1 User's Manual. Analytical Software, Tallahssee, Florida.

17. Cavins TJ \& Dole JM (2001). Photoperiod, juvenility and high intensity lighting affect flowering and cut stem qualities of campanula and lupines. Horticultural Sci 36(7): 11921196.

18. Adams AS, Pearson S \& Hadley $\mathrm{P}$ (1997). The effects of temperature, photoperiod and light integral on the time to flowering of Pansy cv. Universal Violet (Viola $\times$ Wittrockiana Gams.). Annual Bot 80(1): 107-112.

19. Karlsson MG \& Werner JW (2002). The impact of photoperiod and irradiance on flowering of several herbaceous ornamentals. Scientia Horticulturae 10(4): 275-292.

20. Javid QA, Abbasi NA, Hafiz IA \& Mughal AL (2005). Performance of Zinnia (Zinnia elegans) "Dahlia Flowered" Crimson shade by application of NPK fertilizer. Inter $J$ Agric and Biol 7(3): 474-476.

21. Kahar SA (2008). Effects of photoperiod on growth and flowering of Chrysanthemum morifolium Ramat cv. "Reagan Sunny". J of Tropical Agric Food Sci 36(2): 1-8.

22. Khan GA, Sajid M \& Amanulah (2007). Response of Dhalia (Dhalia pinnata) to different levels of nitrogen alone and in combination with constant doses of phosphorus and potassium. American Eurasia $J$ of sustainable Agriculture 1: 25-32.

23. Shafi $M$, Ishtiaq $M \&$ Rehman $N$ (2002). Response of gaillardia pulchella (CV. picta) to different levels of nitrogen with constant doses of phosphorous and potassium. M.Sc (Hons) thesis Department of Horticulture University of Agriculture Peshawar Pakistan.

24. Erwin JE \& Warner RM (2002). Determination of photoperiodic response group and effect of supplemental irradiance on flowering of several bedding plant species. Acta Horticulturae 5(80): 95-100.

25. Ploeg A, Smid HG \& Heuvelink E (2005). Cultivar differences in temperature demand of cut chrysanthemum. Acta Horticulturae 6(11):91-97.

26. Baloch JD, Khan MQ, Munir M \& Zubair M (2010). Effects of different photoperiods on flowering time of facultative short day ornamental annuals. J of Appl Horticul 12(1): 1015.

27. Lokhande SD, Ogawa K, Tanaka A \& Hara T (2003). Effect of temperature on ascorbate peroxidase activity and flowering of Arabidopsis thaliana ecotypes under different light conditions. J of Plant Physiol 160(1): 57-64.

28. Jiang BB, Chen SM, Miao HB, Zhang SM., Chen FD \& Fang WM (2010). Changes of endogenous hormone levels during short day inductive floral initiation and inflorescence differentiation of Chrysanthemum morifolium 'Jingyun'. Inter J of Plant Production 4(2): 149-157. 